\title{
INNOVATION CAPACITY, BUSINESS SOPHISTICATION AND MACROECONOMIC STABILITY: EMPIRICAL EVIDENCE FROM OECD COUNTRIES
}

\author{
Dervis KIRIKKALELI $^{{ }^{1}}{ }^{*}$, Alper OZUN ${ }^{2}$ \\ ${ }^{1}$ Faculty of Economic and Administrative Science, European University of Lefke, \\ Northern Cyprus, TR-10 Mersin, Turkey \\ ${ }^{2}$ Faculty of Law, University of Oxford, London, UK
}

Received 29 May 2018; accepted 08 February 2019

\begin{abstract}
The main aim of this study is to explore the linkages between innovation capacity, business sophistication, and macroeconomic stability within OECD countries. In order to obtain information regarding the relationship between time series variables, the Pedroni cointegration, Kao cointegration, fully modified ordinary least square, dynamic ordinary least square, Granger causality, and Dumitrescu Hurlin causality tests are employed. The empirical results reveal that improvement in business sophistication triggers innovation capacity and support macroeconomic stability. Innovation capacity would also need to be expanded in the long-run, which positively leads to advanced business sophistication that has a cyclical effect. If policymakers intend to accelerate business sophistication, then their attention should be directed towards maximizing the economic indicators in the long-run. To the best of our knowledge, the linkage between innovation capacity, business sophistication and macroeconomic stability in OECD countries has not been comprehensively explored through the use of a single dataset. Thus, the findings of this study could lead to a new debate regarding the concept.
\end{abstract}

Keywords: business sophistication, innovation, macroeconomic stability, OECD countries, panel data modelling, panel causality.

JEL Classification: O31, C33, O14.

\section{Introduction}

In business and economics literatures, macroeconomic stability is an important driver for competitiveness. However, macroeconomic stability itself is not the only driver for competitiveness as there might be more complexities behind a multi-dimensional phenomena like competitiveness. Not only the amount of investment on innovation, but also its quality and success is one of the key component of increasing competitiveness. The impact of innova-

*Corresponding author. E-mail: dkirikkaleli@eul.edu.tr 
tion growth on competitiveness can be even controversial as compared to the impact due to macroeconomic stability. Investment on innovation in unstable financial and macroeconomic periods can create long-term opportunities for positively divergence from international competitiveness.

Similarly, competitiveness should also be supported by business sophistication, in order for it to reach the advanced level requirements needed for global competitiveness. Business sophistication together with innovation have bilateral impacts as they are seen as main pillars of competitiveness especially if an economy is an innovation-driven. However, their relationship cannot be considered isolated from macroeconomic stability that an economy shows. Moreover, business sophistication, which would refer to the quality of business networks and the quality of businesses' operations and strategies, is one of the triggers that foster economic growth through improving efficiency, productivity, and profitability in the market (Dima, Begu, Vasilescu, \& Maassen, 2018). Existing academic researchers in the literature have mainly focused on analysing firm or sector level data to discern an explanation for business innovation, research and development activities, along with the firm or sector level growth (Tsuji, Ueki, Shigeno, Idota, \& Bunno, 2018). To the best of our knowledge, no academic attempt has been made to detect the two-way relationship of business sophistication, innovation, and macroeconomic stability of OECD countries while controlling financial development through the use of a single dataset. In addition, most of the discussions are qualitative and theoretical, which would be in contrast to a provision of evidence through the use of econometric analysis. Therefore, the study aims to open a new debate in this field through this study by filling this gap in the business literature by utilising econometric techniques.

There is a large body of literature pertaining to the effect of technological investments on companies' performance or the relationship between innovation, human capital, and economic development. This is particularly so in cases where human capital is treated to be an important driver for innovation and economic development. However, as stated by Diebold and Hippe (2018), the long-run impact of human capital on innovation and economic development is a black box.

However, when the inter-linkage among innovation, business sophistication and macroeconomic conditions are examined, two main points are underestimated. Firstly, the focus is given on explaining economic growth by amount of innovation spending. In our research, we prefer to focus on if macroeconomic stability is linked with innovation, or vice versa in an economy. From policy making perspective, it is important to have an empirical evidence how investment on innovation impacts competitiveness in the crisis or unstable periods. There might be opportunities to increase innovation growth in unstable macroeconomic periods, which in long-term might create a base for high competitive power. To have an empirical discussion from that perspective, we use macroeconomic stability rather than economic growth and also apply a dummy for the 2008 global crisis in our dataset.

Our research is based on a multi-country dataset that aims to explore the causal and long-run linkage between macroeconomic stability, innovation capacity, and business sophistication in OECD countries that have not been investigated in depth at an earlier stage. The research outcomes are discussed to provide suggestions for long-term sustainable innovation growth and advanced business sophistication. For the empirical analysis, a panel data 
set is constructed observations from the 34 OECD countries between the years of 2006 and 2015. Accordingly, the empirical analysis employs panel techniques to investigate causal and long-run linkages. For this aim, the method applied in the research is Kao cointegration and Pedroni cointegration, fully modified ordinary least squares (FMOLS), dynamic ordinary least squares (DOLS), panel Granger causality, and panel Dumitrescu-Hurlin causality tests. The main hypotheses of this study are as follows:

- There is a significant and positive relation between macroeconomic stability and innovation capacity in the OECD countries

- There is a significant and positive relation between macroeconomic stability and business sophistication in the OECD countries

- There is a significant and positive relation between innovation and business sophistication in the OECD countries

The empirical findings suggest that (i) there is positive linkage between innovation and business sophistication in the long-run; (ii) macroeconomic environment has significant and positive impacts on business sophisticate in the long-run, and vice versa. Both Granger causality and Dumitrescu-Hurlin panel causality tests demonstrated that unidirectional causalities run from business sophistication to innovation and from macroeconomic environment to business sophistication. In addition, the findings also mirror changes in the macroeconomic environment, which would significantly lead to changes in innovation.

The article is organized as follow. The following section discusses the theoretical background on inter linkages between innovation, business sophistication, and economic stability, and presents a recent literature review. In the second section, we describe the panel data sets, and introduce the models and methodologies. The third section presents and discusses the empirical results for each investigated model. The paper will then conclude with a session where some policy suggestions are proposed based on the research outcomes.

\section{Literature review}

In the empirical tests, the long-run linkage between business sophistication, innovation, and macroeconomic environment is examined in OECD countries through the use of three models, while ensure control for the 2008 global crisis and financial market development. The models aim to mirror three different questions, which are as follow: (i) how does innovation and macroeconomic environment affect business sophistication? (ii) how does business sophistication and macroeconomic environment affect innovation?, and (iii) how does business sophistication and innovation affect the economy? From a presentation perspective, it is better to review the literature and discuss the theoretical background based on each of those questions, or each dependent variable, separately.

Innovation is described as the implementation of a new or significantly improved product, goods, service or process, a new marketing method or new organizational method in business practices, workplace organization or external relations (OECD, 2005). Existing empirical and theoretical literature emphasizes that to survive during instability periods, companies and governments must seriously consider investing in innovation. Innovation is thought to be an important driver for the competitive advantage of companies, along with economic growth and the creation of new jobs. 
The studies investigated the linkages between innovation and economic performance, which goes back to the Schumpeterian growth model (Schumpeter, 1934). This linkage is also underlined by Solow-Swan growth model (Solow, 1956; Swan, 1956), and endogenous growth theory (Romer, 1994). In the recent literature, there have been emerged new researches on examining the linkage between innovation, business sophistication and macroeconomic factors (Galindo \& Mendez, 2014). Moreover, some researchers stress the importance of innovation as one of the key drivers of economic development (Bae \& Yoo, 2015). However, previous studies have mainly investigated the impact of innovation towards economic growth by assuming a supply-driven approach of the innovation-growth nexus. Yet, as stated by (Maradana et al., 2017), economic growth can also simulate the level of innovation in the development process, which could lead to a conclusion that there is a bidirectional causality between innovation and economic growth (Pradhan, Arvin, Hall, \& Nair, 2016). Therefore, in the case of this research, bidirectional linkage between innovation and macroeconomic stability is investigated rather than assuming an innovation-growth nexus approach. Among macroeconomic factors, Tomaszewski and Świadek (2017) have highlighted income dynamics as one of the main drivers in innovation growth, according to which, the expectations in relation to income dynamics plays a crucial role in activating innovation rather than the dynamics of (actual) income levels. Furthermore, they empirically show that the expectations on improvement in economic conditions have an additional stimulating effect on innovation activities, while both a recession and its expectation have a de-stimulating effect, concluding that expectations regarding future economic situations are the most important factor when looking at the level of innovation activities that has been neglected so far. This fact that is underlined by Tomaszewski and Świadek (2017) is also one of the reasons as to why macroeconomic stability is used as a variable in this research rather than using actual macroeconomic variables.

Aghion, Askenazy, Berman, Cette, and Eymard (2012) suggest that another reason not to proceed with $\mathrm{R} \& \mathrm{D}$ investments would be the limited credit opportunities during recession, which discourages firms from externally financing their innovation projects. This can affect smaller companies that are more innovation oriented, despite innovation strategies success increasing companies' growth. The growth of smaller firms will be significantly lower compared to those that are more established, and adding the effect of stricter credit opportunities, the return of such an investment can be even more insignificant (Bishop \& Robinson, 2008). Archibugi, Filippetti, and Frenz (2013) examine the relationship between innovation and economic sustainability from a different angle, by using the 2008 economic crisis as a dummy. They point out that the economic crisis caused companies to reduce their investment, including investments in innovation, where returns are uncertain and long-term. Although the cut in innovation spending is not homogeneous across companies, only a minor number of companies increase their innovation expenditures in the crisis period. Their research shows that prior to a crisis, incumbent firms increase their innovation investment, and after the crisis, a few small enterprises have been shown to a "swim against the stream" by expanding their budgets for innovation. Using internal resources for research is a preferred way of financing, primarily due to the lower risk factor and more profitability when compared to external financing. However, during crisis, governments tend to change their 
policies in regard to innovation in order to stabilize the macroeconomic environment of their countries and help keep their economies afloat. Despite this, investment in new knowledge is one of the most important factors in creation of wealth (Czarnitzki \& Hottenrott, 2009), and when governments see that organizations and companies start to cut their investments, it may try to intervene and encourage companies to continue their innovation activities by providing subsidies.

Similar to a macroeconomic environment, business sophistication is expected to impact innovation. Business sophistication focuses on two linked factors, namely the quality of a country's overall business networks and the quality of individual firms' operations and strategies. These factors are specifically important for certain countries, such as an OECD member at an advanced level of development, where the more basic sources of productivity improvements have been exhausted. The firms' advanced operations and strategies (branding, marketing, distribution production of unique and sophisticated products) spill over into the economy and would lead to sophisticated business processes across the country's business sectors. In this context, we can expect a dual causality between business sophistication and innovation. Indeed, it is to our knowledge, this causality has not been empirically tested in the literature. This study thus closes the gap in that respect, while also empirically discussing whether the theoretically expected causality has a long-run nature.

Business sophistication is simply measured by the quality of business networks, business' operations and strategies, which is an important factor that can influence the economic development of countries. Particularly in the timeframe after the global crisis of 2008, businesses have started to not only consider stabilizing, but also about further improving their positions in their respective markets. Business sophistication can also be impacted by a variety of variables, including the political system, macroeconomic environment, and technological improvements. Being able to understand and keep track of macroeconomic vulnerabilities and foresee what may happen, along with having appropriate preparations for it, could thus save the business.

It has been shown that economic cycles have significant effects on companies' profitability, and the ability for a company to keep track of them will decide if a business survives. However, macroeconomic deterioration also has a negative impact on business sophistication, which directly lowers expansion strategies of business. Therefore, it is better to examine the impacts of macroeconomic environment on business sophistication together with innovation growth. Macroeconomic crisis lowers a business' ability to complete acquisitions activities and expansion strategies. When this occurs, cost cutting strategies begin to surface in an attempt to curtail the impact of the crisis. Consequently, the strategy of cost cutting on all fronts could have an adverse effect. During this period, companies could end up cutting funding for some promising opportunities in the long run for a short-term value (Barnett, Musso, \& Padhi, 2009). Against the backdrop of this context, our question, which will be discussed in the empirical session, would be whether it is really necessary to do so for the long-run benefit and sustainable business growth and competitiveness?

In the literature, innovation is considered to be a crucial factor in business growth, as it increases competitiveness through product and process innovation. Dooley and O'Sullivan (2001) and Lafley and Charan (2008) promoted the "learning entity" concept by arguing 
that in order to survive and keep growing, organizations need to constantly and successfully manage changes in the economy for their benefit and to adapt accordingly, and one of the core necessities for this is continuous innovation. Braunerhjelm, Ding, and Thulin (2018) examines the relationship between innovation and firm growth using a Swedish data set and confirm that both exploitative and explorative innovation on firms 'employment growth. Existing research on entrepreneurial orientation primarily examines how entrepreneurial orientation contributes to the performance and survival rate of new ventures. This study develops a conceptual model to examine how innovation speed mediates the relationship between entrepreneurial orientation and performance. To test the proposed theoretical model, we collected data from 153 new ventures. While this study finds that faster innovation speed leads to superior performance, the empirical evidence challenge traditional views. Innovativeness increases, not decreases, innovation speed. Risk-taking reduces, not increases, innovation speed. Finally, proactiveness has inverted U-shaped effects on innovation speed Sahoo and Yadav (2017) examined the effects of entrepreneurial orientation and total quality management on the performance of small- and medium-sized manufacturing enterprises. They found that companies with a higher level of entrepreneurial orientation are more successful in implementing total quality management, which would encourage them to develop new capabilities, allowing them to achieve better performance and business sophistication. Coad (2009) highlights contradictory empirical results in the literature and argues that previous empirical research under different data sets and aggregation levels showed ambiguous results, and that product innovation seems to have a weak positive impact on firm growth.

The stability of the macroeconomic environment is thus significant for the overall competitiveness of a country. It is certainly true that macroeconomic stability alone cannot increase the productivity of an economy; it is also obvious that firms cannot operate efficiently under high inflation environment. Although there are plenty of researches examining the impacts of macroeconomic stability on sophisticated competitive factors, specifically innovation or business sophistication, the research on overall sophisticated factors on economy is limited with regards to economic growth. As an example, Takalo, Tanayama, and Toivanen (2013) show that the effects of innovation positively affects economic growth in the medium and long-term and it improves production potential as well as provides an increase in employment. In addition, government subsidies returns are at least twice the subsidies provided. However, the impacts of innovation and business sophisticate factors on macroeconomic stability, which requires a long-run causality analysis, which, to our knowledge, has yet to be conducted.

Similarly, the quality of business networks, operations, and strategies of business can influence the economic development of countries theoretically. Particularly in the case of developing countries, one of the most important factors that limit the local economic development can be seen as low level business networking. Firms are key actors that use knowledge and technologies to develop competitive products and services, before introducing them to the market (Coenen \& López, 2010; Hekkert, Suurs, Negro, Kuhlmann, \& Smits, 2007). However, the research on this relationship is based on micro level data, and does not distinguish the short and long term effects of business sophistication on macroeconomic stability. For example, Rocha (2012) concluded that encouraging a business environment through sup- 
porting small and medium sized companies can be associated with better living standards, especially for low income households.

Innovation and technology investments are premises for competitiveness and a sustainable economic development. By using multiple regression models with data from Central Eastern Countries, Pece, Simona, and Salisteanu (2015) find a positive relationship between economic growth and innovation. Increasing investments in research and the introduction of new products improve the living condition of the population and lead to developments in both the public and private sectors. Dima et al. (2018) investigated the impacts of knowledge economy on country competitiveness in the European Union by using Perason coefficient and panel-data regression models. The findings show the key role of innovation and education as main determinants of European Union economic convergence. Similarly, Ciocanel and Pavalescu (2015) empirically examined the nexus between innovation and competitiveness in the European Union, concluding that a focus on research and innovation activities can significantly contribute to the competitiveness and economic sustainability of the Union. Kacprzyk and Doryń (2017) examines the innovation-growth nexus in the European Union (EU) countries over the period 1993-2011 to test if patent activities and different research and development would affect economic growth in the old (EU-15) and new (EU-13) member states differently. They find that there are no significant impacts of R\&D on the growth and that there was a positive relationship between patent activities and growth in the EU13. They conclude that setting common numerical targets in the EU innovation policy may not be the optimum policy from an economic standpoint. This research closes a gap in the literature by examining causal and long-term relationship between innovation, business sophistication, and macroeconomic stability, and provides a substantial source for long-term policy discussions pertaining to OECD countries.

\section{Data and methodology}

The empirical tests use three variables, namely business sophistication, innovation and macroeconomic environment gathered from the World Economic Forum. The data sets include observations from 34 OECD countries that cover the period of 2006-2015. The variables and their codes are demonstrated in Table 1.

Table 1. Data

\begin{tabular}{|l|l|c|}
\hline \multicolumn{1}{|c|}{ Data } & \multicolumn{1}{c|}{ Source } & Code \\
\hline Business Sophistication & World Economic Forum & BUS \\
\hline Innovation & World Economic Forum & INO \\
\hline Macroeconomic Environment & World Economic Forum & MAC \\
\hline Financial Market Development & World Economic Forum & FMD \\
\hline 2008 Global Crisis & & DUM \\
\hline
\end{tabular}

Figure 1 shows the average macroeconomic environment, innovation capacity, and business sophistication in the 34 OECD countries between 2006 and 2015. It also clearly mirrors 

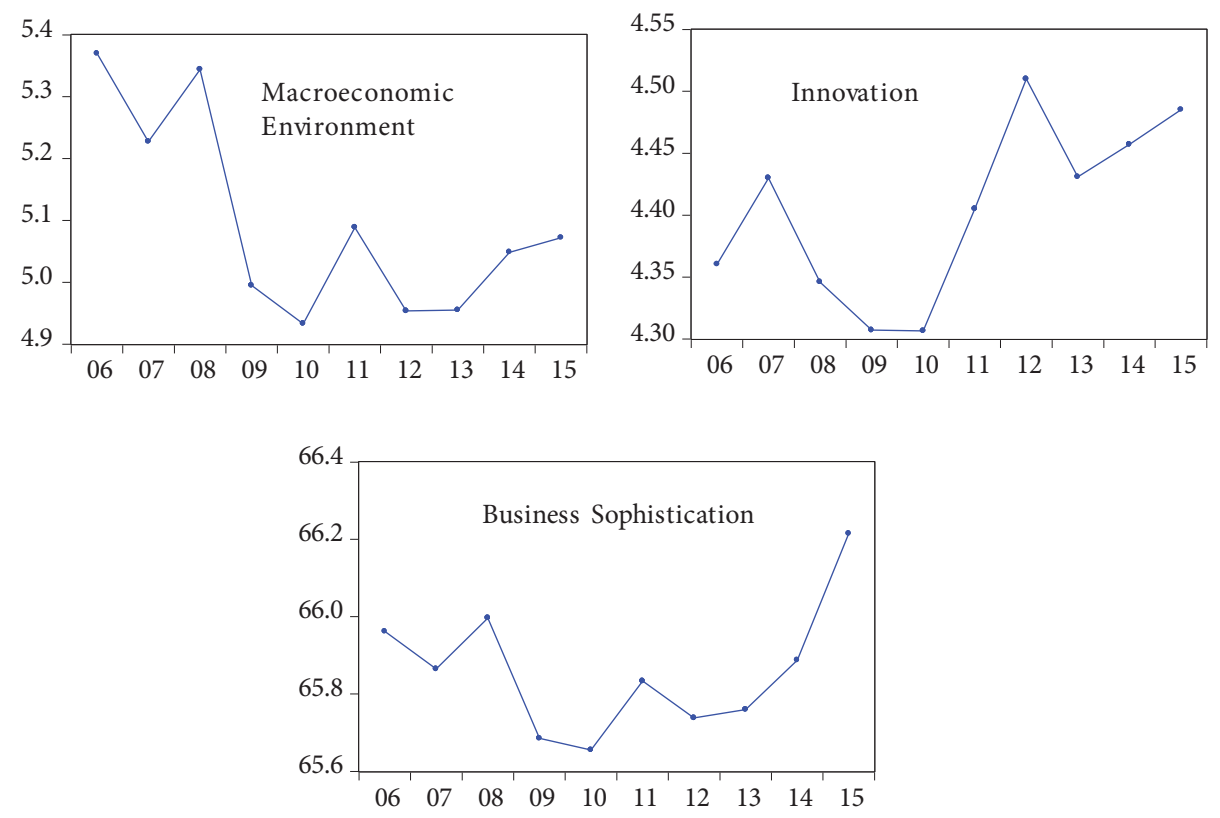

Figure 1. Macroeconomic Environment, Innovation and Business Sophistication in the OECD countries

the dramatic effect of the 2007-08 Global crisis in the macroeconomic environment, business sophistication and innovation variables. Both the macroeconomic and business environments in OECD countries were affected by the 2008 Global crisis from 2008 to the beginning of 2010. What is curious is that innovation was hit the same time in those periods, but from 2010 it had started to show an upward trend, which may indicate that the OECD countries used policies to become more innovative, with this decision helping the business and macroeconomic environments to remain steady rather than decline. This view will be discussed in further detail in the last section. Due to its dramatic effects on the datasets, a dummy variable is used to represent the 2008 global crisis in the empirical tests of this study.

Among the OECD countries, the best macroeconomic performance on average was achieved by Norway. In terms of innovative capacity, Finland is ranked topmost in the world, while Japan had the highest average score for business sophistication globally. Greece looked weakest in terms of macroeconomic performance, and she struggled not only in the macroeconomic performance, but also in business sophistication and innovation capacity, ranking the lowest within the OECD countries due to her debt crisis. To explore the relationship between business sophistication, innovation and macroeconomic environment in the OECD countries, three different models are employed, while employing controls for the 2008 global crisis and financial market development. The equations of the models are shown below.

$$
\begin{aligned}
& \mathrm{BUS}_{\mathrm{it}}=\rho_{\mathrm{it}}+v_{1 \mathrm{i}} \mathrm{INO}+v_{2 \mathrm{i}} \mathrm{MAC}+v_{3 \mathrm{i}} \mathrm{FMD}+v_{4 \mathrm{i}} \mathrm{DUM}+\mathrm{e}_{\mathrm{it}} ; \\
& \mathrm{INO}_{\mathrm{it}}=\rho^{\mathrm{o}}{ }_{\mathrm{it}}+v^{\mathrm{o}}{ }_{\mathrm{i}} \mathrm{BUS}+v^{\mathrm{o}}{ }_{\mathrm{i}} \mathrm{MAC}+v^{\mathrm{o} 3}{ }_{\mathrm{i}} \mathrm{FMD}+v^{\mathrm{o} 4} \mathrm{D} \mathrm{DUM}+\mathrm{e}^{\mathrm{o}}{ }_{\mathrm{it}} ; \\
& \mathrm{MAC}_{\mathrm{it}}=\rho_{\mathrm{it}}^{\mathrm{c}}+v^{\mathrm{c}} 1_{1 \mathrm{i}} \mathrm{BUS}+v^{\mathrm{c}}{ }_{2 \mathrm{i}} \mathrm{INO}+v^{\mathrm{c}}{ }_{3 \mathrm{i}} \mathrm{FMD}+v^{\mathrm{c}}{ }_{4 \mathrm{i}} \mathrm{DUM}+\mathrm{e}_{\mathrm{it}} .
\end{aligned}
$$


In these equations, $\rho_{\mathrm{i}}, \rho^{\mathrm{o}}{ }_{\text {it }}$ and $\rho_{\text {it }}^{\mathrm{c}}$ indicate country specific effects and $\mathrm{e}_{\mathrm{it}}, \mathrm{e}^{\mathrm{o}}{ }_{\text {it }}$ and $\mathrm{e}^{\mathrm{c}}{ }_{\text {it }}$ is the residual term. $\mathrm{i}=1,2 \ldots, \mathrm{N}$ and $\mathrm{t}=1,2 . ., \mathrm{T}$, show panel members and time periods, respectively.

To detect the order of integration of each variable, LLC, IPS, ADF-Fisher and PP-Fisher panel unit root tests are employed. As a next step, cointegration equation among the variables is checked by using two different tests, namely, the Pedroni cointegration test proposed by Pedroni (2001) and the Kao panel cointegration test developed by Kao (1999). The Pedroni cointegration test is based on pooling within dimensions, which allow for heterogeneity in the autoregressive term. To support the results, the Kao panel cointegration test is applied, which is known as a robust cointegration test when used in panel data.

To examine the long-run linkage among the variables, Fully Modified Ordinary Least Squares (FMOLS) and Dynamic Ordinary Least Squares (DOLS) techniques are employed. The main advantage of FMOLS and DOLS tests can be seen in the case of correcting endogeneity bias and serial correlations. Therefore, these tests allow for standard normal inference (Carlsson, Lyhagen, \& Österholm, 2007). DOLS is a parametric approach where lagged first-differenced terms are explicitly estimated. The equations of the three models are then rebuilt as follows:

$$
\begin{gathered}
\mathrm{BUS}_{\text {it }}=\alpha_{\mathrm{i}}+\beta_{1 \mathrm{i}} \mathrm{INO}_{\mathrm{it}}+\beta_{2 \mathrm{i}} \mathrm{MAC}_{\mathrm{it}}+\beta_{3 \mathrm{i}} \mathrm{FMD}_{\mathrm{it}}+\beta_{4 \mathrm{i}} \mathrm{DUM}_{\mathrm{it}}+\mathrm{e}_{\mathrm{it}} \\
\mathrm{i}=1,2, \ldots, \mathrm{N}, \mathrm{t}=1,2, \ldots, \mathrm{T} ; \\
\mathrm{INO}_{\mathrm{it}}=\alpha_{\mathrm{i}}+\beta_{5 \mathrm{i}} \mathrm{BUS}_{\mathrm{it}}+\beta_{6 \mathrm{i}} \mathrm{MAC}_{\mathrm{it}}+\beta_{7 \mathrm{i}} \mathrm{FMD}_{\mathrm{it}}+\beta_{8 \mathrm{i}} \mathrm{DUM}_{\mathrm{it}}+\mathrm{e}_{\mathrm{it}} \\
\mathrm{i}=1,2, \ldots, \mathrm{N}, \mathrm{t}=1,2, \ldots, \mathrm{T} \\
\mathrm{MAC}_{\mathrm{it}}=\alpha_{\mathrm{i}}+\beta_{9 \mathrm{i}} \mathrm{BUS}_{\mathrm{it}}+\beta_{10 \mathrm{i}} \mathrm{INO}_{\mathrm{it}}+\beta_{11 \mathrm{i}} \mathrm{FMD}_{\mathrm{it}}+\beta_{12 \mathrm{i}} \mathrm{DUM}_{\mathrm{it}}+\mathrm{e}_{\mathrm{it}} \\
\mathrm{i}=1,2, \ldots, \mathrm{N}, \mathrm{t}=1,2, \ldots, \mathrm{T} .
\end{gathered}
$$

Finally, panel-based Granger and Dumitrescu-Hurlin causality tests are applied to discover the causal relationship between the business sophistication, innovation, and macroeconomic environment in the OECD countries. The basic equations of the Granger causality test for the $\mathrm{F}_{\mathrm{t}}$ and $\mathrm{H}_{\mathrm{t}}$ variables are shown in the following equations:

$$
\begin{aligned}
& \mathrm{F}_{\mathrm{t}}=\alpha_{1}+\sum_{i=1}^{n} \beta_{1 \mathrm{i}} \mathrm{H}_{\mathrm{t}-\mathrm{i}}+\sum_{i=1}^{n} \beta_{2 \mathrm{i}} \mathrm{F}_{\mathrm{t}-\mathrm{i}}+\mathrm{e}_{1 \mathrm{t}} \\
& \mathrm{H}=\alpha_{2}+\sum_{i=1}^{n} \beta_{3 \mathrm{i}} \mathrm{H}_{\mathrm{t}-\mathrm{i}}+\sum_{i=1}^{n} \beta_{4 \mathrm{i}} \mathrm{F}_{\mathrm{t}-\mathrm{i}}+\mathrm{e}_{2 \mathrm{t}} .
\end{aligned}
$$

Where $n$ denotes the number of lags, $\alpha_{1}, \alpha_{2}, \beta_{1}, \beta_{2}, \beta_{3}$, and $\beta_{4}$ are parameters to be estimated, and $e_{1 \mathrm{t}}$ and $\mathrm{e}_{2 \mathrm{t}}$ are error terms. If variable $\mathrm{H}$ does not cause variable $\mathrm{F}$, the parameters of $\mathrm{F}$ on the lagged $\mathrm{H}$ are mutually zero.

By involving cross-sectional units in the model, a panel-based Granger causality test is developed by Dumitrescu and Hurlin (2012). For the two stationary variables, F and H are observed over $T$ periods on $N$ individuals. Their equation is given as follows:

$$
\mathrm{F}_{\mathrm{i}, \mathrm{t}}=\mathrm{v}_{\mathrm{t}}+\sum_{c=1}^{C} \mu^{(\mathrm{c})} \mathrm{F}_{\mathrm{i}, \mathrm{t}-\mathrm{c}}+\sum_{c=1}^{C} \beta^{(\mathrm{c})} \mathrm{H}_{\mathrm{i}, \mathrm{t}-\mathrm{c}}+\mathrm{u}_{\mathrm{i}, \mathrm{t}},
$$

where $\mathrm{u}$ is an error term. 


\section{Empirical finding}

Before starting any empirical tests, the stationarity in the data is checked by performing LLC, which was proposed by Levin, Lin, and Chu (2002), IPS, developed by Im, Pesaran, and Shin (2003), ADF-Fisher, PP-Fisher, and proposed by Maddala and Wu (1999) and Choi (2001) to detect the integration of order of variables. For each unit root test, the models are performed with (i) a constant only, and (i) a deterministic trend and a constant. While IPS, ADF-Fisher and PP-Fisher tests allow for individual unit root process, the autocorrelation coefficients that vary across cross sections LLC test allows for common unit root process across cross sections. In all panel unit root tests, the null hypothesis is that variables have a unit root; for the alternative hypothesis, they do not have a unit root.

Table 2. Panel Unit Root Test (source: author's calculations)

\begin{tabular}{|c|c|c|c|c|}
\hline & \multirow[t]{2}{*}{$\begin{array}{l}\text { Levin, Lin and Chu } \\
\quad \text { (LLC) t-stat }\end{array}$} & $\begin{array}{l}\text { Im, Pesaran } \\
\text { and Shin }\end{array}$ & $\begin{array}{c}\text { Augmented Dickey } \\
\text { Fuller-Fisher } \\
\text { (ADF - Fisher) }\end{array}$ & $\begin{array}{c}\text { Phillips Perron- } \\
\text { Fisher } \\
\text { (PP-Fisher) }\end{array}$ \\
\hline & & (IPS) W-stat & Chi-square & Chi-square \\
\hline \multicolumn{5}{|c|}{ Series in Levels } \\
\hline BUS & \multirow{3}{*}{$\begin{array}{c}-3.68(0.00)^{\star *} \\
-6.36(0.00)^{\star *} \\
-1.01(0.15)\end{array}$} & $-0.06(0.47)$ & $63.06(0.64)$ & $65.12(0.57)$ \\
\hline INO & & $-1.27(0.10)$ & $9.12(0.16)$ & $84.64(0.08)$ \\
\hline MAC & & $-0.20(0.41)$ & $74.31(0.28)$ & $86.20(0.06)$ \\
\hline FMD & $-4.54(0.00)^{\star \star}$ & $0.88(0.81)$ & $59.63(0.75)$ & $77.50(20.14)$ \\
\hline \multicolumn{5}{|c|}{ Series in First Differences } \\
\hline BUS & \multirow{3}{*}{$\begin{array}{l}-8.70(0.00)^{\star \star} \\
-11.15(0.00)^{\star \star} \\
-30.01(0.00)^{\star \star}\end{array}$} & $-3.15(0.00)^{\star \star}$ & $113.98(0.00)^{\star \star}$ & $116.90(0.00)^{\star \star}$ \\
\hline INO & & $-4.32(0.00)^{* *}$ & $138.83(0.00)^{\star *}$ & $133.55(0.00)^{\star *}$ \\
\hline MAC & & $-12.09(0.00)^{\star *}$ & $245.75(0.00)^{\star *}$ & $296.92(0.00)^{\star \star}$ \\
\hline FMD & $-10.66(0.00)^{\star \star}$ & $-3.73(0.00)^{\star \star}$ & $127.99(0.00)^{\star *}$ & $141.51(0.00)^{* \star}$ \\
\hline
\end{tabular}

Note: ${ }^{* *}$, and ${ }^{*}$ denote statistical significance at the $1 \%$, and $5 \%$ levels, respectively. ( ) denotes the p-values. The unit root models are performed by including only constant term.

After detecting the integration of order of the variables and finding them as a (1), Pedroni and Kao panel cointegration techniques were further employed to investigate the long-run cointegration linkage among the time series variables. The findings of Panel based Pedroni and Kao cointegration tests are shown in Table 3.

Table 2 shows the findings from the panel-based unit root test. The majority of the results from the unit root test reveal that the null hypothesis of the time series variables have no unit root at a $5 \%$ level and can be rejected for the variables, suggesting that the variables are not I (0). However, at the first difference, the results of the panel based unit root tests mirrors that the variables seems stationary which implies that the variables are I (1). These findings permit us to investigate long-run cointegration equation among the variables using Pedroni and Kao cointegration tests. The majority of outcomes of Pedroni cointegration test clearly reveal that the null hypothesis of no co-integration in all models can be rejected at a $5 \%$ level, indicating that there is long-run cointegration equation between business sophistication, 
innovation and macroeconomic environment in OECD countries. The outcome of the Kao cointegration tests support this findings as well, as shown in Table 3.

Table 3. Panel Cointegration Test (source: author's calculations)

\begin{tabular}{|c|c|c|c|c|c|c|c|}
\hline \multicolumn{6}{|c|}{ Pedroni Residual Cointegration Test } & \multicolumn{2}{|c|}{$\begin{array}{c}\text { Kao Residual } \\
\text { Cointegration Test }\end{array}$} \\
\hline \multicolumn{8}{|c|}{ Model 1. BUS INO MAC FMD DUM } \\
\hline & W-statistic & Prob. & & Statistic & Prob. & $\begin{array}{c}\mathrm{ADF} \\
\text { T-statistic }\end{array}$ & Prob. \\
\hline $\begin{array}{l}\text { Panel } \\
\text { v-Statistic }\end{array}$ & -1.97 & 0.97 & $\begin{array}{l}\text { Group } \\
\text { rho- } \\
\text { Statistic }\end{array}$ & 6.83 & 1.00 & -6.04 & $0.00^{*}$ \\
\hline $\begin{array}{l}\text { Panel rho- } \\
\text { Statistic }\end{array}$ & 4.42 & 1.00 & $\begin{array}{l}\text { Group PP- } \\
\text { Statistic }\end{array}$ & -15.33 & $0.00^{*}$ & & \\
\hline $\begin{array}{l}\text { Panel PP- } \\
\text { Statistic }\end{array}$ & -9.38 & $0.00^{*}$ & \begin{tabular}{|l|} 
Group \\
ADF- \\
Statistic
\end{tabular} & -10.05 & $0.00^{*}$ & & \\
\hline $\begin{array}{l}\text { Panel ADF- } \\
\text { Statistic }\end{array}$ & -6.61 & $0.00^{\star}$ & & & & & \\
\hline \multicolumn{8}{|c|}{ Model 2. INO BUS MAC FMD DUM } \\
\hline & W-statistic & Prob. & & & & $\begin{array}{c}\text { ADF } \\
\text { T-statistic }\end{array}$ & Prob. \\
\hline $\begin{array}{l}\text { Panel } \\
\text { v-Statistic }\end{array}$ & -2.75 & 0.99 & $\begin{array}{l}\text { Group } \\
\text { rho- } \\
\text { Statistic }\end{array}$ & 7.06 & 1.00 & -1.84 & $0.03^{*}$ \\
\hline $\begin{array}{l}\text { Panel rho- } \\
\text { Statistic }\end{array}$ & 4.71 & 1.00 & $\begin{array}{l}\text { Group PP- } \\
\text { Statistic }\end{array}$ & -14.96 & $0.00^{*}$ & & \\
\hline $\begin{array}{l}\text { Panel PP- } \\
\text { Statistic }\end{array}$ & -7.99 & $0.00^{*}$ & $\begin{array}{l}\text { Group } \\
\text { ADF- } \\
\text { Statistic }\end{array}$ & -9.99 & $0.00^{*}$ & & \\
\hline $\begin{array}{l}\text { Panel ADF- } \\
\text { Statistic }\end{array}$ & -5.31 & $0.00^{*}$ & & & & & \\
\hline \multicolumn{8}{|c|}{ Model 3. MAC BUS INO FMD DUM } \\
\hline & W-statistic & Prob. & & & & $\begin{array}{c}\text { ADF } \\
\text { T-statistic }\end{array}$ & Prob. \\
\hline $\begin{array}{l}\text { Panel } \\
\text { v-Statistic }\end{array}$ & -2.85 & 0.99 & $\begin{array}{l}\text { Group } \\
\text { rho- } \\
\text { Statistic }\end{array}$ & 6.36 & 1.00 & -2.14 & $0.01^{*}$ \\
\hline $\begin{array}{l}\text { Panel rho- } \\
\text { Statistic }\end{array}$ & 4.11 & 1.00 & $\begin{array}{l}\text { Group } \\
\text { PP- } \\
\text { Statistic }\end{array}$ & -27.05 & $0.00^{*}$ & & \\
\hline $\begin{array}{l}\text { Panel PP- } \\
\text { Statistic }\end{array}$ & -13.70 & $0.00^{*}$ & \begin{tabular}{|l|} 
Group \\
ADF- \\
Statistic
\end{tabular} & -12.82 & $0.00^{*}$ & & \\
\hline $\begin{array}{l}\text { Panel ADF- } \\
\text { Statistic }\end{array}$ & -8.43 & $0.00^{*}$ & & & & & \\
\hline
\end{tabular}

Note: ${ }^{*}$ denote statistical significance at the $5 \%$ level. W-statistic denote- Weighted Statistic. 
To have a cointegration equation among the variables allows us to perform FMOLS and DOLS techniques to investigate the size and sign of relationship among the variables. The outcome of the FMOLS and DOLS techniques are presented in Table 4. In the first model, where we investigate the impacts of macroeconomic environment and innovation on business sophistication, the findings reveal that the coefficients of innovation ranges between 0.22 and 0.32 in both the models with and without the control for the 2008 global crisis and financial market development, indicating that around $1 \%$ increase in the innovation leads to an approximate $1 / 4 \%$ increase in business sophistication in OECD countries. This finding is in line with the finding of Dooley and O'Sullivan (2001) and Lafley and Charan (2008) which underlined the importance of innovation on business growth. The FMOLS and DOLS estimates of the elasticity of the macroeconomic environment with respect to business sophistication range from 0.11 under the model without control for the 2008 global crisis and financial market development to 0.06 under the model with control for the 2008 global crisis and financial market development. The coefficients are statistically significant and positive, implying that the macroeconomic environment has a positive effect on business sophistication.

In the second model, the effect of business sophistication and macroeconomic environment on innovation is observed and the findings in both models that show that rising business sophistication is associated with better innovation environment in OECD countries. Surprisingly, the findings suggest that there is no significant effect of the macroeconomic environment on innovation. In the last model, business sophistication in the FMOLS models between and within dimensions had a statistical significant and positive effect on macroeconomic environment in the long-run. The coefficients are positive, significant, and range between 0.60 and 0.77 , showing how important the business sophistication is on macroeconomic environment. This empirical finding is consistent with the findings of Rocha (2012), Coenen and López (2010), and Hekkert et al. (2007). Moreover, this finding empirically supports the theoretical argument of Malecki (2018) which argues that one of the economic development indicators in a country is the growth of small and large firms' growth. These results are in line with the results of the models with control for the 2008 global crisis and financial market development. The results also reveal that innovation alone does not significantly affect the macroeconomic environment in the long-run.

The findings from the panel-based Granger causality and Dumitrescu-Hurlin panel causality tests are reported in Table 5. Both techniques evidently mirror the null hypothesis that macroeconomic environment and business sophistication do not cause innovation and can be rejected at the $10 \%$ level. The findings also show that the variations in the macroeconomic environment and business sophistication can lead to changes in the innovation capacity of OECD countries. Furthermore, the findings from the Dumitrescu Hurlin causality technique are in line with the findings from the Granger causality test. These results illustrate the importance of the macroeconomic environment and business sophistication on the innovation capacity of OECD countries. The findings also suggest that change in macroeconomic environment significantly lead to change in business sophistication. 


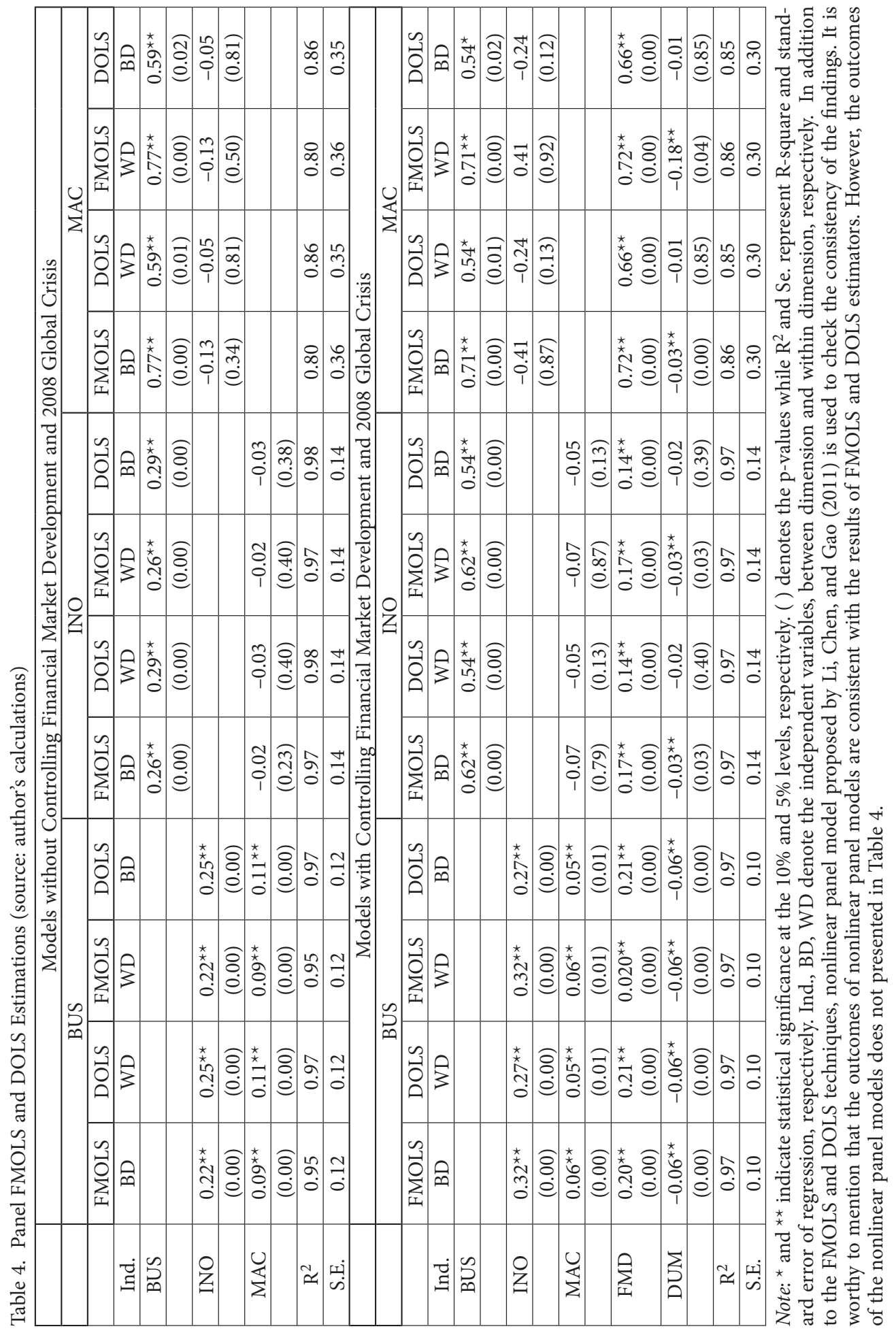


Table 5. Panel Causality Tests (source: author's calculations)

\begin{tabular}{|l|c|c|c|}
\hline \multicolumn{4}{|c|}{ Granger Causality Panel Test } \\
\hline & & F-Statistic & Prob. \\
\hline INO does not Granger Cause BUS & & 0.996 & 0.395 \\
\hline BUS does not Granger Cause INO & & 2.480 & $0.062^{\star}$ \\
\hline MAC does not Granger Cause BUS & & 2.616 & $0.053^{\star}$ \\
\hline BUS does not Granger Cause MAC & & 0.054 & 0.983 \\
\hline MAC does not Granger Cause INO & & 5.485 & $0.001^{\star *}$ \\
\hline INO does not Granger Cause MAC & 0.574 & 0.632 \\
\hline \multicolumn{1}{|c|}{ Dumitrescu Hurlin Panel Causality Test } \\
\hline & W-Stat. & Zbar-Stat. & Prob. \\
\hline INO does not homogeneously cause BUS & 2.413 & 0.923 & 0.355 \\
\hline BUS does not homogeneously cause INO & 4.387 & 3.365 & $0.000^{* *}$ \\
\hline MAC does not homogeneously cause BUS & 3.764 & 2.594 & $0.009^{* *}$ \\
\hline BUS does not homogeneously cause MAC & 1.893 & 0.279 & 0.779 \\
\hline MAC does not homogeneously cause INO & 4.422 & 3.426 & $0.000^{\star *}$ \\
\hline INO does not homogeneously cause MAC & 1.850 & 0.227 & 0.819 \\
\hline
\end{tabular}

Note: ${ }^{\star}$ and ${ }^{\star \star}$ indicate statistical significance at the $10 \%$ and $5 \%$ levels, respectively.

\section{Conclusions}

There is considerable research on the impact of business environment and innovation on productivity and efficiency but two-way long-run and causal relationship between business sophistication, innovation and macroeconomic environment has not been examined extensively in previous literature. In this research paper, we filled this vacuum in the case of OECD countries and sought to reopen policy debates about how policymakers can simulate innovation and business sophistication to help global competitiveness.

We used business sophistication, economic environment and innovation capacity datasets from The World Economic Forum, covering a period of 2006 and 2015, and performed Pedroni cointegration, Kao cointegration, FMOLS, DOLS, Granger Causality, and Dumitrescu Hurlin Causality tests. The finding from these techniques bring to light influential evidence that (i) there is positive link between innovation capacity and business sophistication in the long-run; (ii) macroeconomic environment has significant and positive impacts on business sophistication in the long-run, and vice versa. In addition, both Granger causality and Dumitrescu-Hurlin panel causality tests reveal that unidirectional causalities run from business sophistication to innovation and from macroeconomic environment to business sophistication. The findings also mirror that changes found in macroeconomic environment that significantly lead to changes in innovation.

These empirical findings provide some important policy recommendations for OECD countries. First, policymakers should facilitate business sophistication to accelerate its growth through supporting local suppliers to increase their production range, production quality, 
production process sophistication, and breadth of value chain, and make laws to facilitate the efficiency of the business industry. Improvement in business sophistication triggers better macroeconomic environment and increases innovation capacity. Second, the innovation capacity of the OECD countries should be expanded in the long-run, which will then positively impact growth in business sophistication. This will then have a cyclical effect as increasing business activities would accelerate innovation capacity, too. This result is rational and in line with the findings of Geroski and Toker (1996), Geroski and Machin (1993) and Bishop and Robinson (2008). Finally, if policymakers in OECD countries intend to accelerate business sophistication, then their attention should be directed towards stabilising macroeconomic indicators in the long-run.

There are two main limitations in this study. One is that only the dataset of 10 years were used in the models. In this study, the estimations are conducted for the period of 2006-2015. Although this study provides strong empirical findings, further studies should be conducted as new datasets are released. Another limitation is that this study only takes into account OECD countries. Therefore, further research should be conducted in different regions of the world in order to identify deeper results.

\section{References}

Aghion, P., Askenazy, P., Berman, N., Cette, G., \& Eymard, L. (2012). Credit constraints and the cyclicality of R\&D investment: Evidence from France. Journal of the European Economic Association, 10(5), 1001-1024. https://doi.org/10.1111/j.1542-4774.2012.01093.x

Archibugi, D., Filippetti, A., \& Frenz, M. (2013). Economic crisis and innovation: Is destruction prevailing over accumulation?. Research Policy, 42(2), 303-314. https://doi.org/10.1016/j.respol.2012.07.002

Bae, S. H., \& Yoo, K. (2015). Economic modeling of innovation in the creative industries and its implications. Technological Forecasting and Social Change, 96, 101-110. https://doi.org/10.1016/j.techfore.2015.02.010

Barrett, C. W., Musso, C. S., \& Padhi, A. (2009). Upgrading R\&D in a downturn. The McKinsey Quarterly, 2(February), 1-3.

Bishop, K., \& Robinson, C. (2008). Business growth and innovation: The wider impact of rapidly-growing firms in UK city-regions (No. 2476). National Institute of Economic and Social Research.

Braunerhjelm, P., Ding, D., \& Thulin, P. (2018). The knowledge spillover theory of intrapreneurship. Small Business Economics, 51(1), 1-30. https://doi.org/10.1007/s11187-017-9928-9

Carlsson, M., Lyhagen, J., \& Österholm, P. (2007). Testing for purchasing power parity in cointegrated panels (No. 7-287). International Monetary Fund.

Choi, I. (2001). Unit root tests for panel data. Journal of International Money and Finance, 20(2), 249272. https://doi.org/10.1016/S0261-5606(00)00048-6

Ciocanel, A. B., \& Pavelescu, F. M. (2015). Innovation and competitiveness in European context. Procedia Economics and Finance, 32, 728-737. https://doi.org/10.1016/S2212-5671(15)01455-0

Coad, A. (2009). The growth of firms: A survey of theories and empirical evidence. Edward Elgar Publishing. https://doi.org/10.4337/9781848449107

Coenen, L., \& López, F. J. D. (2010). Comparing systems approaches to innovation and technological change for sustainable and competitive economies: an explorative study into conceptual commonalities, differences and complementarities. Journal of Cleaner Production, 18(12), 1149-1160. https://doi.org/10.1016/j.jclepro.2010.04.003 
Czarnitzki, D., \& Hottenrott, H. (2009). Are local milieus the key to innovation performance?. Journal of Regional Science, 49(1), 81-112. https://doi.org/10.1111/j.1467-9787.2008.00584.x

Diebolt, C., \& Hippe, R. (2018). The long-run impact of human capital on innovation and economic development in the regions of Europe. Applied Economics, 1-22. https://doi.org/10.1080/00036846.2018.1495820

Dima, A. M., Begu, L., Vasilescu, M. D., \& Maassen, M. A. (2018). The relationship between the knowledge economy and global competitiveness in the European Union. Sustainability, 10(6), 1706. https://doi.org/10.3390/su10061706

Dooley, L., \& O'Sullivan, D. (2001). Structuring innovation: A conceptual model and implementation methodology. Enterprise and Innovation Management Studies, 2(3), 177-194. https://doi.org/10.1080/14632440110101246

Dumitrescu, E. I., \& Hurlin, C. (2012). Testing for Granger non-causality in heterogeneous panels. Economic Modelling, 29(4), 1450-1460. https://doi.org/10.1016/j.econmod.2012.02.014

Galindo, M. Á., \& Méndez, M. T. (2014). Entrepreneurship, economic growth, and innovation: Are feedback effects at work?. Journal of Business Research, 67(5), 825-829. https://doi.org/10.1016/j.jbusres.2013.11.052

Geroski, P. A., \& Machin, S. (1993). Innovation, profitability and growth over the business cycle. Empirica, 20(1), 35-50. https://doi.org/10.1007/BF01384139

Geroski, P. A., Machin, S. J., \& Walters, C. F. (1997). Corporate growth and profitability. The Journal of Industrial Economics, 45(2), 171-189. https://doi.org/10.1111/1467-6451.00042

Geroski, P. A., \& Toker, S. (1996). The turnover of market leaders in UK manufacturing industry, 197986. International Journal of Industrial Organization, 14(2), 141-158. https://doi.org/10.1016/0167-7187(95)00479-3

Hekkert, M. P., Suurs, R. A., Negro, S. O., Kuhlmann, S., \& Smits, R. E. (2007). Functions of innovation systems: A new approach for analysing technological change. Technological Forecasting and Social Change, 74(4), 413-432. https://doi.org/10.1016/j.techfore.2006.03.002

Im, K. S., Pesaran, M. H., \& Shin, Y. (2003). Testing for unit roots in heterogeneous panels. Journal of Econometrics, 115(1), 53-74. https://doi.org/10.1016/S0304-4076(03)00092-7

Kacprzyk, A., \& Doryń, W. (2017). Innovation and economic growth in old and new member states of the European Union. Economic Research - Ekonomska istraživanja, 30(1), 1724-1742. https://doi.org/10.1080/1331677X.2017.1383176

Kao, C. (1999). Spurious regression and residual-based tests for cointegration in panel data. Journal of Econometrics, 90(1), 1-44. https://doi.org/10.1016/S0304-4076(98)00023-2

Lafley, A. G., \& Charan, R. (2008). The game-changer: How you can drive revenue and profit growth with innovation. Crown Business.

Levin, A., Lin, C. F., \& Chu, C. S. J. (2002). Unit root tests in panel data: asymptotic and finite-sample properties. Journal of Econometrics, 108(1), 1-24. https://doi.org/10.1016/S0304-4076(01)00098-7

Li, D., Chen, J., \& Gao, J. (2011). Non-parametric time-varying coefficient panel data models with fixed effects. The Econometrics Journal, 14(3), 387-408. https://doi.org/10.1111/j.1368-423X.2011.00350.x

Maddala, G. S., \& Wu, S. (1999). A comparative study of unit root tests with panel data and a new simple test. Oxford Bulletin of Economics and Statistics, 61(S1), 631-652. https://doi.org/10.1111/1468-0084.0610s1631

Malecki, E. J. (2018). Entrepreneurs, networks, and economic development: A review of recent research. In Reflections and extensions on key papers of the first twenty-five years of advances (pp. 71-116). Emerald Publishing Limited. https://doi.org/10.1108/S1074-754020180000020010

Maradana, R. P., Pradhan, R. P., Dash, S., Gaurav, K., Jayakumar, M., \& Chatterjee, D. (2017). Does innovation promote economic growth? Evidence from European countries. Journal of Innovation and Entrepreneurship, 6(1), 1. https://doi.org/10.1186/s13731-016-0061-9 
OECD. (2005). Oslo Manual: Guidelines for collecting and interpreting innovation data. Paris.

Pece, A. M., Simona, O. E. O., \& Salisteanu, F. (2015). Innovation and economic growth: An empirical analysis for CEE countries. Procedia Economics and Finance, 26, 461-467. https://doi.org/10.1016/S2212-5671(15)00874-6

Pedroni, P. (2001). Fully modified OLS for heterogeneous cointegrated panels. In Nonstationary panels, panel cointegration, and dynamic panels (pp. 93-130). Emerald Group Publishing Limited.

Pradhan, R. P., Arvin, M. B., Hall, J. H., \& Nair, M. (2016). Innovation, financial development and economic growth in Eurozone countries. Applied Economics Letters, 23(16), 1141-1144. https://doi.org/10.1080/13504851.2016.1139668

Rocha, E. A. G. (2012). The impact of the business environment on the size of the micro, small and medium enterprise sector; preliminary findings from a cross-country comparison. Procedia Economics and Finance, 4, 335-349. https://doi.org/10.1016/S2212-5671(12)00348-6

Romer, P. M. (1994). The origins of endogenous growth. Journal of Economic Perspectives, 8(1), 3-22. https://doi.org/10.1257/jep.8.1.3

Sahoo, S., \& Yadav, S. (2017). Entrepreneurial orientation of SMEs, total quality management and firm performance. Journal of Manufacturing Technology Management, 28(7), 892-912. https://doi.org/10.1108/JMTM-04-2017-0064

Schumpeter, J. A. (1934). Change and the Entrepreneur. Essays of JA Schumpeter. Routledge.

Solow, R. M. (1956). A contribution to the theory of economic growth. The Quarterly Journal of Economics, 70(1), 65-94. https://doi.org/10.2307/1884513

Swan, T. W. (1956). Economic growth and capital accumulation. Economic Record, 32(2), 334-361. https://doi.org/10.1111/j.1475-4932.1956.tb00434.x

Takalo, T., Tanayama, T., \& Toivanen, O. (2013). Estimating the benefits of targeted R\&D subsidies. Review of Economics and Statistics, 95(1), 255-272. https://doi.org/10.1162/REST_a_00280

Tomaszewski, M., \& Świadek, A. (2017). The impact of the economic conditions on the innovation activity of the companies from selected Balkan states. Economic Research - Ekonomska istraživanja, 30(1), 1896-1913. https://doi.org/10.1080/1331677X.2017.1398099

Tsuji, M., Ueki, Y., Shigeno, H., Idota, H., \& Bunno, T. (2018). R\&D and non-R\&D in the innovation process among firms in ASEAN countries: Based on firm-level survey data. European Journal of Management and Business Economics, 27(2), 198-214. https://doi.org/10.1186/s13731-016-0061-9 